\title{
The Value Relevance of Foreign Income: An Australian, Canadian, and British Comparison
}

\author{
Gordon M. Bodnar \\ Morris W. Offit Professor of International Finance \\ Paul H. Nitze School of Advanced International Studies \\ Johns Hopkins University \\ Washington, DC 20036 \\ (202) 663-7731 \\ bodnar@jhu.edu \\ Lee Seok Hwang \\ Department of Accounting \\ Chinese University of Hong Kong \\ and \\ School of Business Administration \\ Baruch College, New York, N.Y. 10010 \\ and \\ Joseph Weintrop* \\ Stan Ross Professor \\ Department of Accounting \\ School of Business Administration \\ Baruch College, New York, N.Y. 10010 \\ (646) 312-2185
}

October 10, 2001

* contact author

The authors wish to thank participants at the 1999 American Accounting Association Annual Meetings and an anonymous referee for comments. We also acknowledge the Disclosure Company for providing us with World Scope and Columbia University for funding through a CIBER grant. 


\title{
The Value Relevance of Geographical Segment Disclosure: An Australian, Canadian, and British Comparison
}

\begin{abstract}
In this paper we examine the value-relevance of geographical earnings disclosures for firms listed and domiciled in Australia, Canada and the United Kingdom. We find that foreign earnings in all three countries are valued differently than domestic earnings. The estimate of the association coefficient for foreign earnings changes with returns is positive in all three countries and statistically larger than the association coefficient for domestic earnings changes in Canada and the United Kingdom. Further tests show that this difference is related to relative growth opportunities of overseas operations to domestic operations. These findings are similar to results for foreign earnings association coefficients for American-based multinationals found in Bodnar and Weintrop (1997). These results indicate that across countries the market perceives the results of foreign operations as value relevant and suggests that, greater emphasis should be placed on the required disclosure of segmental data rather than on the concern that all countries prepare the segmental information using a common GAAP.
\end{abstract}

Keywords: Foreign Income, Valuation, Growth Opportunities, 


\section{Introduction}

As the world continues to globalize, the foreign operations of corporations are becoming increasingly relevant as a source of value. However, in only a few countries are firms required to make detailed disclosures of their foreign operations, despite the fact that foreign operations can experience patterns of profitability, growth, and risk that differ from those of the consolidated operations. Given the increasing importance of foreign operations, surprisingly little research has been done on the valuerelevance of such disclosures for investors and what any differential market reactions tell us about the economic characteristics of foreign operations relative to those of domestic operations.

In one of the earliest studies on geographic disclosures, Boatsman, Behn and Patz (1993) demonstrated that regional foreign income disclosures were not value-relevant for US multinational firms' returns beyond their part in total income. However, in a more recent evaluation of the value relevance of regional geographic data, Thomas (2000) finds some support for the value relevance of geographical segmental data with stock returns over three-year windows. Bodnar and Weintrop (1997) consider the value relevance but consider the less ambiguous decomposition of earnings into just domestic and foreign components. For a large set of U.S. multinational firms, they find value relevance for foreign income disclosures by demonstrating that changes in foreign income are more positively associated with annual equity returns changes in domestic income. After further investigations they conclude that the difference results from the market pricing greater opportunities for future income growth from successful foreign operations than successful domestic operations.

A second line of investigation is offered in Garrod and Rees (1998). They use foreign segment data to extend the Ohlson (1995) valuation model and study the earnings and book values for multinational firms in the United Kingdom. They find that United Kingdom multinational firms are more highly valued than United Kingdom domestic firms. They also investigate the value impact of foreign operations. While they fail to detect a significant premium for the total foreign operations, they do report that operations in the U.S. are more highly valued than operations than other areas. 
In this paper, we follow the approach of Bodnar and Weintrop (1997), and look at the issue of value relevance of aggregate foreign income disclosures for a set of non-U.S. firms. The reason for preferring this approach for non-U.S. countries is two-fold. First, firms in countries other the U.S., if they make geographic disclosures, are more likely to disclosure only non domestic income, and as such trying to look at regional geographic disclosures results in an extremely small sample. ${ }^{1}$ Second, if firms do disclose the regions that they operate in, a review of financial statements demonstrates that there is no commonality in the selection of the particular segments.

Given this methodological decision, the goals of this paper are to determine if foreign income disclosures are value-relevant under GAAP environments other than the U.S. and to determine if the market's perception of the economic characteristics of foreign income in these countries are consistent with those found in the U.S. by Bodnar and Weintrop (1997). Ideally, such a study would like to examine a large set of countries in order to carry out cross sectional tests; however, until recently, very few countries have mandated the disclosure of income on a geographic basis for their multinational firms. As a result, we examine the value-relevance of foreign income in those three countries that have mandated foreign income segment disclosures since 1990: Australia, Canada, and the United Kingdom. While the differences in GAAP among these countries are not that significant, this cross section of countries allow us to determine if the value relevance of foreign income disclosures is a fundamental economic phenomenon or a peculiarity of the US market or accounting system. Further, specific tests use changes in income components that mitigate concerns over specific differences in accounting policies.

Using data from 444 Australian firm-years, 891 Canadian firm-years and 738 British firm-years, from 1990 - 1998, we find that changes in foreign income have a positive association with annual returns for all three countries. For Canada and the United Kingdom, the foreign income association is significantly larger than the domestic income association with annual returns while for Australia the difference is only marginally larger across the full sample of firms. This evidence suggests that, as in the

\footnotetext{
${ }^{1}$ Foreign revenues are also commonly disclosed. For purposes of our tests, there is limited evidence of the value relevance for geographic revenue disclosures for domestic or foreign firms.
} 
U.S., foreign income disclosures are incrementally value-relevant to investors and that foreign income is more highly associated with annual returns than domestic income. We also conduct tests to examine whether the larger foreign association coefficient is related to greater growth opportunities for foreign operations. Using relative sales growth as a measure of relative future growth opportunities, we find that the foreign income association coefficients in all three countries are larger than domestic income association coefficients when foreign growth opportunities are higher than domestic growth opportunities. Finally, we demonstrate that the results are robust to the elimination of negative income realizations and the inclusion of income levels.

We provide further evidence that, despite differences in income determination across these countries, the economic consequences associated with the disclosure of foreign income are the same. Market participants evaluate income from foreign sources differently from income from domestic operations, and in particular its changes are more highly associated with annual returns. This underlines the importance of geographic segmental disclosures across markets. These findings have implication for the international accounting regulatory bodies as they consider moves toward global standards. This suggests that a movement towards weaker segmental disclosure requirements, such as those of the new United States segmental disclosure rule, SFAS No. 131, will result in a reduction of value-relevant information for investors about multinational firms. ${ }^{2}$

The remainder of the paper is organized as follows. The next section develops the methodology and discusses the relevant theoretical prediction for the empirical section. Section 3 describes the sample selection and Section 4 presents the basic empirical findings. Section 5 provides some investigation of the economic explanations of the results and Section 6 provides some investigation of the economic explanation for the results. Finally, Section 7 concludes.

\footnotetext{
${ }^{2}$ Herman and Thomas (2000) demonstrate that the new SFAS No. 131 disclosure requirements have resulted in smaller percentage of U.S. firms reporting geographic income relative to the disclosure requirements of the previous SFAS No. 14.
} 


\section{Methodology:}

The concept of a multi-country study of the value-relevance of income goes back to Alford, Jones, Leftwich and Zmijewski (1993) who address the issue of the value-relevance of annual earnings prepared under different GAAP applications. For a sample of 18 countries from 1982 to 1990, they document a positive association between earnings and returns. Among the 18 countries they examined were Australia, Canada, and the United Kingdom. With the establishment of the commonality of an earnings/returns relation, researchers have moved to determine if firms' supplemental disclosures are also associated with annual returns across countries that use different GAAPs. We choose geographically segmented income data as the supplemental disclosure because of the importance that foreign operations play for the largest firms in these countries. Disclosures of foreign operations should be of importance to investors of firms with significant foreign operations if foreign and domestic operations are subject to different risks and returns as is commonly believed in practice.

The issue of supplemental foreign data has been an area that accounting regulators have long deemed as important to investors. In the United States, the Securities and Exchange Commission first mandated disclosure of geographic segment information in 1969 as part of their segmented disclosure requirements in Accounting Series Releases and extended it to all publicly traded firms in $1970 .^{3}$ According to these rules, a firm was required to identify segments providing 10 percent or more of consolidated revenue and/or earnings. In 1976, the Financial Accounting Standards Board (FASB) adopted measures (SFAS No. 14) very similar in nature to the SEC requirement and added the additional criterion that disclosure was required if more than 10 percent of the total assets of the firm was in one segment. Segments were defined as both service/product lines and geographic location, as well as export sales or major customers. Central to the reasons for including geographic segments was the belief of the

\footnotetext{
3 See Swaminathan (1991) for an extended discussion on the history of the expansion of foreign data disclosures in the United States.
} 
regulatory bodies that information contained in geographic operations is relevant to financial statement users. $^{4}$

Outside the United States, geographic segment disclosures are not as common, though there is a growing recognition of their importance. This view is reflected in the geographic segmental disclosure requirements currently outlined within the context of the International Accounting Standards No. 14 (IAS \#14), Financial Reporting Information by Segment. ${ }^{5}$ This March 1981 regulation was intended to aid the users of financial statement, “...to access the effect that operations in different industries and in different geographical area may have on the enterprise as a whole". ${ }^{6}$ The major disclosure requirements are to provide data on segmental revenues, income and assets when a segment exceeded a $10 \%$ threshold.

In addition to this accounting standard, the European Economic Community recommends geographic disclosures for both financial and non-financial results of a firm's multinational operations. Their Fourth Directive requires that sales be segregated by categories of activity and geographic market to the extent that these categories and markets differ substantially from one another. The Organization of Economic Cooperation and Development's Guides for Multinational Enterprises also suggests a series of geographic disclosures of operating revenues and sales by geographic area. They also ask for disclosure of significant new capital projects and the average number of employees in each geographical area.

For the three countries of our study, Australia, Canada, and the United Kingdom, foreign segment disclosures have been mandated since at least $1990 .^{7}$ Unlike many other foreign countries where disclosures are voluntary, and largely limited to revenues, these three countries all mandate similar disclosures as in the U.S., requiring reporting of foreign sales, assets and income. In all cases, the geographic disclosures we study are provided in terms of the GAAP of the primary reporting country. Thus, a company incorporated in the Australia, will use Australian GAAP for its supplemental disclosures

\footnotetext{
${ }^{4}$ More recently, the U.S. has adopted SFAS No. 131. One implication of this new statement for fiscal years 1998 and beyond is the dropping of the requirement of mandated foreign income disclosures.

${ }^{5}$ We direct the reader to Choi and Mueller (1992), pp. 324-330 for a more detailed history of these disclosure issues.

6 Ibid., par. 5.

${ }^{7}$ We direct the reader to Choi and Mueller Table 7.1. In this table, the disclose requirements for thirteen stock markets are provided. Of interest to this study is item $4 \mathrm{~g}$, segmental financial information in Australia, Canada and the United Kingdom.
} 
(similarly for Canadian and U.K. firms). For the purposes of our study, each of these countries reflects the regulatory policies of the local stock exchange (the Sydney Stock Exchanges for Australia, the Toronto Stock Exchange for Canada and the London Stock Exchange for the United Kingdom).

\subsection{Model Development}

Our interest is to examine the association of foreign income changes with annual equity returns for the sample firms. This allows us to test for the incremental value-relevance of foreign income beyond total income and provides us insights about market perceptions of future investment and production opportunities outside of the home country. Foreign operations, wherever located, face risks (currency, legal and political) and opportunities (new markets) that differ fundamentally from domestic operations. These differences suggest that foreign income disclosures could have incremental explanatory power for returns than domestic income. The nature of any incremental explanatory power could provide insights into the differential economic characteristics of foreign income relative to domestic income.

The standard association regression in accounting was originally tested by Ball and Brown (1968) for U.S. firms and also used by Alford et al. (1993) for non U.S. firms. In it, changes in the firm's market value are regressed against changes in components of consolidated earnings ${ }^{8}$.

$$
\Delta \mathrm{V}_{\mathrm{i}, \mathrm{t}}=\alpha_{0}+\alpha_{1} \Delta \mathrm{TERN}_{\mathrm{i}, \mathrm{t}}+\varepsilon_{\mathrm{i}, \mathrm{t}}
$$

where $\Delta \mathrm{V}_{\mathrm{i}, \mathrm{t}}=$ the change in the market value of firm $\mathrm{i}$ over the reporting period $\mathrm{t}$

$\Delta$ TERN $_{\mathrm{i}, \mathrm{t}}=$ the change in total earnings of firm $\mathrm{i}$ over period $\mathrm{t}$.

The association coefficients, $\alpha_{1}$, provide a measure of the sensitivity of firm value to reported earnings, respectively. Theoretically, if markets are efficient and earnings follow a simple random walk, the association coefficient would be equal to one over the firm's cost of capital. ${ }^{9}$

\footnotetext{
${ }^{8}$ The studies cited rely on the net income. As we will demonstrate later, we are constrained by data availability and we are only able secure foreign operating income and thus modify our theory appropriately.

${ }^{9}$ In a simple model, where earnings streams are assumed to evolve randomly and the value of the firm is equal to the present discounted value of the earnings stream, it is possible to show that the association coefficient between an earnings change and
} 
For the purposes of studying foreign operating income disclosures, one can modify equation (1) by adding the change in foreign income.

$$
\Delta \mathrm{V}_{\mathrm{i}, \mathrm{t}}=\gamma_{0}+\gamma_{1} \Delta \text { TERN }_{\mathrm{i}, \mathrm{t}}+\gamma_{2} \Delta \text { FOPERN }_{\mathrm{i}, \mathrm{t}}+\varepsilon_{\mathrm{i}, \mathrm{t}}
$$

Where: FERN $\mathrm{i}_{\mathrm{i}, \mathrm{t}}$ is the change in foreign income for firm $\mathrm{i}$ in period $\mathrm{t}$.

In this specification, $\gamma_{1}$ now represents the association coefficient for the domestic portion of the income change and $\gamma_{2}$ is the incremental association coefficient for foreign income. This is because of the perfect decomposition of total income into domestic and foreign income. The full association of the foreign income with returns is given by $\gamma_{1}+\gamma_{2}$. Thus from equation (2), $\gamma_{2}$ is the coefficient of interest in determining whether the association of foreign income is significantly different from that of domestic operating income. A significant incremental foreign association coefficient, $\gamma_{2}$, would imply that foreign income disclosures are incrementally value relevant.

There are several economic arguments as to whether the sign of the incremental foreign association coefficient, $\gamma_{2}$, should be positive or negative. One argument is that foreign earnings could be valued less highly than domestic earnings by the market because they are perceived to be less reliable and/or more uncertain. Foreign income streams can be more uncertain in economic value as they face more risk factors than domestic income, including greater business cycle volatility and currency gyrations. In addition, actions by foreign governments can make the availability to shareholders of future and current foreign earnings less certain than domestic income. Because of this greater risk and lower reliability, foreign operations may require a higher of rate of return on such activities. This higher rate of return implies a higher discount rate for foreign income than domestic income resulting in a lower association of foreign income changes with returns. Reported foreign operating income may also be less representative of true economic conditions than domestic operating earnings because of additional

the market value of the firm will be equal to one over the market discount rate for that stream of earnings (see, e.g., Collins and Kothari (1989)). 
accounting techniques required to translate them from foreign currency into domestic currency making there reported value less value relevant. ${ }^{10}$

On the other hand, there are reasons that foreign association coefficients could be larger than domestic association coefficients. One explanation is that despite their added volatility exchange rate changes work to make foreign operating income changes more persistent because exchange rate changes are themselves highly persistent, (see, e.g., Messe and Rogoff (1983) and Frankel and Rose (1995)). If the influence of exchange rate results in foreign earnings being more persistent that domestic operating earnings, a change in foreign earnings today would have a larger impact on value than an equivalent change in domestic earnings. ${ }^{11}$ Another reason could be the greater use of conservative accounting methods in newer (i.e., foreign) operations. For example, in a new segment, the auditor may ask for more aggressive expense recognition and more conservative revenue recognition until the segment establishes itself and some uncertainty has been resolved. If auditors require a greater use of conservative accounting procedures in foreign activities because of their newness, this would result in larger multiples for foreign income.

An additional reason for a larger foreign association coefficient relates to differences in growth opportunities between foreign and domestic operations. Collins and Kothari (1989) demonstrate that association coefficients are a positive function of the firm's future growth opportunities. Because in the normal evolution of multinational firms, foreign operations typically follow the development of successful domestic operations, it is possible that successful foreign operations indicate greater opportunities for future growth than the more established domestic operations. This would be consistent with the view that foreign operations represent expansions into new, less exploited markets (see, e.g.,

\footnotetext{
${ }^{10}$ This is true of the temporal method of foreign currency consolidation used by foreign operations that have designated the U.S. dollar as functional currency. For more on this problem, see Bartov and Bodnar (1996).

11 Permanent changes in earnings by definition should lead to a larger impact on price today as the present value of the impact is larger than for a similar-sized temporary change in earnings. Easton and Harris (1991) argue that under the specification of earnings as a random walk, changes in earnings represent permanent components and levels of earnings represent temporary components. They include both earnings levels and changes in a single regression with returns and find the earnings response coefficient for changes to be higher than it is for levels. Of course the influence of the exchange rate will only result in larger foreign association coefficients to the extent that changes in foreign currency income are no less predictable or perceived less permanent than changes in domestic income.
} 
Kogut (1983) and Stopford and Wells (1972)). If foreign operations currently offer greater growth opportunities than domestic operations, then one would expect a larger association between firm value and foreign income than between firm value and domestic income.

\section{Data and Sample Selection}

To test the value relevance of foreign income disclosures in Australia, Canada and the United Kingdom, it is necessary to obtain samples of firms that disclose foreign income and (for subsequent tests) foreign revenues. We obtain this information from the WorldScope database from Disclosure. The version of WorldScope we use is October 1999 and it provides data on firms' disclosure of their foreign operations for the 10-year period from 1989 to 1998 in the form of percentages of total. ${ }^{12}$ In these three countries, WorldScope reports percentages for foreign sales, foreign operating income, and foreign assets, as percentages of the consolidated totals. Data on consolidated values for sales, operating income, and assets are taken from WorldScope and cross-checked with data from Compustat's Global Vantage for each firm. These consolidated figures are combined with the WorldScope ratios to construct the nominal figures for foreign sales, operating income and assets. All values are reported in the firms' home currency.

It is also important to note that the geographic segment disclosures in these countries are available only at the operating income level and not the net income level. In the next sections, all of our comparisons of domestic versus foreign association coefficients are done at the operating income level. Since non-operating income may also be value relevant, we also require data on the total non-operating income (the difference between operating income and net income) for each firm. This data is available only on a consolidated basis.

\footnotetext{
${ }^{12}$ Worldscope reports the foreign percentages down to basis points. It also provides data on the absolute amounts of foreign variables in units of billions of local currency. These figures are too crude to accurately measure changes for most firms.
} 
In order for a firm to remain in the sample, we require two consecutive years of data for operating income and sales as well as the foreign percentages for each. The two consecutive years of accounting data are needed to calculate change variables.

The dependent variable in our analysis is a twelve-month domestic-market adjusted return (MAR) for the firm, measured in the domestic currency. To calculate this variable, we need stock prices, dividends, and share changes which we obtain from the Global Vantage. The return is calculated from year-end prices adjusted for stock splits and stock/cash dividends plus the value of cash dividends per share distributed during the holding period. To control for common return influences within a country, we adjust each firm's twelve-month return by the corresponding annual return to the local market index. ${ }^{13}$ The local market index is determined forming an equally-weighted portfolio of all of the firms on the exchange.

In our study, the placement of the window to accumulate the annual return is based on the country-specific regulations regarding the public release of the accounting data. ${ }^{14}$ For example in Great Britain, firms are required to file financial statements 120 days after the year-end, so we calculate our market-adjusted returns over a twelve month period ending four months after the close of the fiscal year end. ${ }^{15}$ We also use the price at the beginning of the return measurement period to normalize the income variables.

For the purposes of our study, we are only interested in the securities of the firms in the country of their incorporation. Thus a firm incorporated in Canada (with its head office in Canada) is considered only in the Canadian tests even if the firm was listed on other exchanges around the world. In addition we delete firms in the financial services industries because their foreign revenues disclosures are not readily comparable to the non-financial firms that dominate the sample.

\footnotetext{
${ }^{13}$ We obtain fundamentally similar results with all our tests when we use raw returns instead of market adjusted returns.

${ }^{14}$ Alford et al. (1993, Table 1) provide data on the different reporting requirements of firms when it comes to making their data publicly available.

${ }^{15}$ We direct the reader to Alford et al. (Table 1). We found no deviations from this listing and so these represent the timing lags we used to calculate our window of market adjusted returns.
} 
These data requirements result in a sample of 444 firm-year Australian observations, 891 Canadian firm-year observations, and 738 U.K. firm-year observations. Table 1 provides some summary statistics on these firms. Across the three countries, as expected when dealing with multinationals, these are large firms, with median assets of approximately in the range of US\$400MM in the U.K. to US\$550MM in Australia. Moreover, the median observations indicate a significant degree of foreign revenues and income, with the third quartile observations in both Canada and the UK having a majority of their income coming from abroad. Table 2 reports the summary statistics for the regression variables used in the next section.

\section{Empirical Tests}

We begin our empirical tests by verifying that each country in our sample demonstrates a significant positive relation between changes in annual earnings and returns similar in nature to those reported by Alford et al. (1993). Equation (3) provides empirical specification where the change in total net income is broken into the change in total operating income and the change in non-operating income.

$$
\text { MAR }_{\mathrm{i}, \mathrm{t}}=\alpha_{0}+\alpha_{1} \frac{\Delta \mathrm{TOPEPS}_{\mathrm{i}, \mathrm{t}}}{\mathrm{P}_{\mathrm{i}, \mathrm{t}-1}}+\alpha_{1} \frac{\Delta \mathrm{TNOPEPS}_{\mathrm{i}, \mathrm{t}}}{\mathrm{P}_{\mathrm{i}, \mathrm{t}-1}}+\varepsilon_{\mathrm{i}, \mathrm{t}}
$$

where: $\mathrm{MAR}_{\mathrm{i}, \mathrm{t}}$, is market adjusted change in firm's i stock price over the year $\mathrm{t}$, $\triangle$ TOPEPS $_{i, t}$ is the change in total operating earnings for firm $\mathrm{i}$ in year $\mathrm{t}$, $\triangle$ TNOPEPS $_{i, t}$ is the change in total non-operating earnings for firm $\mathrm{i}$ in year $\mathrm{t}$, $\mathrm{P}_{\mathrm{i}, \mathrm{t}-1}$, is firm i's share price at the beginning of the return accumulation period, time $\mathrm{t}-1$, used to normalize the income per share info $\varepsilon_{\mathrm{i}, \mathrm{t}}$ is the error term for firm i at time t. ${ }^{16}$

We are forced to use this specification since our data on foreign income is at the operating level. The results of regression (3) for each country are reported in Panel A of Table $3 .{ }^{17}$ As expected, all three 
countries produce a positive and highly significant coefficient on the change in operating and nonoperating earnings per share. Since the change in net income is by definition the sum of these two terms, the association coefficient for net income is the sum of the two association coefficients $\left(\alpha_{1}+\alpha_{2}\right)$. It is not surprising that net income is slightly, but significantly, more associated with annual return than is operating income. These results are logically consistent with Alford et al. (1993) and indicate the value relevance of these two net income components.

Having established the association of operating and net income with returns in these three countries, we now move on to test whether the foreign operating income disclosure is value-relevant. We do this by modifying equation (3) in the same fashion that we modified equation (1) by adding the change in foreign operating income over price $\left(\triangle F O P E P S_{i, t} / P_{i, t-1}\right)$ as an additional variable to the original regression.

$$
M_{i, t}=\delta_{0}+\delta_{1} \frac{\Delta \text { TOPEPS }_{i, t}}{P_{i, t-1}}+\delta_{2} \frac{\Delta \text { TNOPEPS }_{i, t}}{P_{i, t-1}}+\delta_{3} \frac{\Delta \text { POPEPS }_{i, t}}{P_{i, t-1}}+\varepsilon_{i, t}
$$

Panel B of Table 3 provides the results of this regression for Australia, Canada and the United Kingdom. For all three countries the association coefficient on the total change in operating income, which now measures the association of the domestic component of operating income, has decreased relative to the estimates in Panel A, but remain statistically significant. The association coefficient on the change in non-operating income remains positive and statistically significant. The association coefficient on the change in foreign operating income is positive and statistically significant at conventional levels for Canada and the United Kingdom, and is positive and significant at the $11 \%$ level for Australia. The consistent positive value indicates that the association of foreign operating income is larger than that of domestic operating income for all three countries. For Australia, the incremental foreign association coefficient is 0.43 , implying a total foreign operating income association coefficient of 1.44 , for Canada,

\footnotetext{
16 The use of a naive prediction for operating and non-operating earnings expectations on a per share is consistent with Boatsman et al. (1993) and Alford et al. (1993). See Christie (1987) for a discussion of the division by price at the beginning of the period.
} 
the incremental foreign association coefficient is 0.62 implying a total foreign operating income association coefficient of 1.53 , and for the U.K, the incremental foreign association coefficient is 0.92 , implying a total foreign operating income association coefficient of 2.72 .

This finding of a meaningfully positive incremental foreign income association coefficient is consistent with similar results for the U.S. shown in Bodnar and Weintrop (1997). Together these results support the claim that market participants find foreign income disclosures incrementally useful when determining the value of multinational firms and that it appears to be an economic phenomenon that changes in foreign income are more positively related with returns than are changes in domestic income. The commonality of this result across four countries despite differences in GAAP suggests that this is because of because of fundamental characteristics of foreign income. In the next section we examine if the same economic explanation for this phenomenon in the US is supported in these countries.

\section{Economic Explanation}

The result of a positive incremental association coefficient for foreign income for Canada, the U.K., and Australia (though marginally significant) is consistent with the U.S. results of Bodnar and Weintrop (1997). As mentioned above, there are several possible explanation for the more positive association of foreign income than domestic income. Bodnar and Weintrop (1997) investigate several of these possibilities and find support for the growth opportunities story by demonstrating that the size of the incremental foreign association coefficient is related to the relative growth opportunities in the foreign segment proxied for by relative sales growth each segment. ${ }^{18}$ Drawing upon the fact that previous research had demonstrated a positive link between growth opportunities and association coefficients, they interpreted their result as indicating the market's perception of greater growth opportunities from successful foreign operations. In this subsection we carry out a similar analysis to see if the same

\footnotetext{
${ }^{17}$ The regressions are screened for overly influential observations using a standard Cook's Distance test and tests winsorizing the top and bottom $1 \%$ do not change the qualitative nature of the conclusions.
} 
economic phenomenon will explain the positive incremental foreign association coefficients in these three countries.

Following the approach of Bodnar and Weintrop (1997), we use the firm's segmental disclosures on foreign sales from WorldScope to calculate percentage changes in foreign and domestic sales over the previous year. The sample is then portioned into two groups based upon the relative sales growths in these two regions. In the first group are the observations where domestic sales growth is larger than foreign sales growth over the previous year and in the second group are those observations where foreign sales growth is as large as, or larger than domestic sales growth.

If relative foreign - domestic sales growth proxies for the market's perception of relative growth opportunities between foreign and domestic operations, and greater growth opportunities are related to more positive association coefficients, then we should expect to see different results across sub samples with different relative regional sales growth. For the case where domestic sales growth is greater than foreign sales growth, there is no signal of greater foreign growth opportunities and we would expect that there should be no significant incremental foreign association coefficient. The reason we might not expect the foreign association coefficients to significantly smaller is that we know that unconditionally the effect is positive and it is often the case that firms expand overseas only after exhausting most of the growth opportunities at home so this situation might not necessarily indicate substantially more growth opportunities at home than abroad. In the second case, where foreign sales growth surpasses domestic sales growth signaling greater foreign growth opportunities, we should expect to see large and significant incremental foreign association coefficients.

This test is run on equation (4), and the results on the two subsamples are reported in Table 4. In Panel A, where domestic sales growth outpaces foreign sales growth, we see no evidence that the foreign association coefficient is statistically larger than the domestic association coefficient. For two of the three countries (Canada and the U.K.) the incremental foreign association coefficient is not significantly

\footnotetext{
${ }^{18}$ They also investigated the issue of the persistence of the exchange rate change by decomposing the foreign income into exchange rate and foreign currency components. The removal of the foreign exchange rate component had no detectible effect
} 
different from zero, while for Australia, it is actually significantly smaller than the domestic association coefficient. However, in Panel B, when foreign sales growth outpaces domestic sales growth, we see consistent and significant evidence of a positive incremental foreign association coefficient for all three countries. In this sub sample, the incremental foreign association coefficient is larger and more significant than in the unconditional regression reported in Panel B of Table 3. Together the two panels of Table 4 indicate that the phenomenon of significantly larger foreign association coefficients is related to relative regional sales growth.

This result is qualitatively the same as that found for the U.S. firms in Bodnar and Weintrop (1997). The foreign association coefficients are significant and positive and the incremental foreign association coefficient is related to the relative regional sales growth (which acts as a proxy for incremental growth opportunities). Thus, these results point to the conclusion that this effect is not unique to the U.S. or its accounting system, but more likely a fundamental feature of the market's perception of firms' foreign income. As such, it points to the importance and value-relevance of providing investor's specific information on firm's foreign operations.

\section{Robustness Checks}

In this section we consider two specific adjustments of the specified model to examine the robustness of our results. First, a possible concern about interpreting these results is the omitted variables problem. Recent work on the relation between earnings and returns (see, e.g., Easton and Harris (1995) and Ali and Zarowin (1992)) has demonstrated that in addition to the change in earnings, the level of earnings is an important explanatory variable for annual returns. The rationale behind the importance of the level of earnings relates to its ability to capture transitory components of earnings above the permanent component of earnings that are captured in the earnings change. Based upon these studies, we add the level of total operating income, foreign operating income and total non-operating income 
(normalized by beginning of period price) to our empirical specification. This allows to us to check whether our incremental foreign association coefficient result is driven by the omission of the level of earnings. While the relation between income levels are equity returns are not well defined beyond statistical issues, we do not provide predictions for the coefficients on the income level variables, other than to suggest that foreign income should on average be more permanent, suggesting a less important relation between returns and foreign income levels than with returns and domestic income levels.

A second potential problem in interpreting the size of association coefficients is the impact of negative income realizations. As negative income is not a sensible long run forecast (as the firm would eventually go under) negative income realization must be expected to be temporary. Therefore, the change in income, when income turns negative, will have a lower association with returns than income changes when income is positive (see Hayn (1995)). This bias could be driving our results if the firms in our sample reported negative income realizations more frequently for domestic income than for foreign income. To determine whether this problem is driving the results in Panel B of Table 4, we create dummy variables to separate out those cases where reported income, domestic, foreign, in both changes and levels, is negative. These new variables are NEG_ATOPEPS/P, NEG_AFOPEPS/P, for negative change in total and foreign operations and NEG_TOPEPS/P and NEG_FOPEPS/P to represent negative levels of total and foreign operations, respectively. These variable are assigned the value of the income variable when the realized value of the income variable is less than zero for that period, and are zero otherwise. As a result, these variables represent the differences in the association coefficients when the particular income realization

We test the combined effects of the levels and changes and the issues of negative earnings in equations (5).

$$
\begin{aligned}
\text { MAR }_{i, t} & =\omega_{0}+\omega_{1} \frac{\text { TOPEPS }_{i, t}}{P_{i, t-1}} \omega_{2} \frac{N E G_{-} \text {TOPEPS }_{i, t}}{P_{i, t-1}}+\omega_{3} \frac{\Delta T O P E P S_{i, t}}{P_{i, t-1}}+\omega_{4} \frac{N E G_{-} \Delta T O P E P S_{i, t}}{P_{i, t-1}}+\omega_{5} \frac{\text { FOPEPS }_{i, t}}{P_{i, t-1}} \\
& +\omega_{6} \frac{N E G_{-} F O P E P S_{i, t}}{P_{i, t-1}}+\omega_{7} \frac{\Delta F O P E P S_{i, t}}{P_{i, t-1}}+\omega_{8} \frac{N E G_{-} \Delta F O P E P S_{i, t}}{P_{i, t-1}}+\omega_{9} \frac{T N O P E P S_{i, t}}{P_{i, t-1}} \omega_{10} \frac{\Delta T N O P E P S_{i, t}}{P_{i, t-1}}+\varepsilon_{i, t}
\end{aligned}
$$


The results of estimating equation (5) are reported in Table 5. In Panel A of Table 5, we report our findings where the domestic sales growth is greater than the foreign sales growth. Consistent with previous research the level of total operating income is statistically significant for all three countries. As suggested, the association of the foreign income level is either not different from domestic income or is significantly smaller (in the case of Australia). While the change in total operating income remains significant in Canada and the U.K., the incremental association coefficient for the change in foreign operating income remains insignificant except for the U.K. were it is now positive (0.51) and significant.

Panel B of Table 5 reveals results for subsample when the foreign sales growth is greater than domestic sales growth. It is interesting to note that the level of total income is not as significant as in Panel A, perhaps because the income change is perceived as more permanent. Once again, the coefficient on the level of foreign income is not significantly different from zero. In support of our conclusions from Table 4, even with the addition of income levels and the separation of negative income realizations the incremental association coefficient on the foreign income change is positive. For Canada and the U.K. it is significant while for Australia it is marginally significant at the $11 \%$ level. Thus despite our limited sample sizes these robustness tests that include income levels and separate out negative income realizations do not provide any compelling evidence against original findings or our interpretation of the phenomena.

\section{Summary and Conclusions}

In the United States there have been mandated disclosure requirements of geographic revenues, income and assets since 1976. Bodnar and Weintrop (1997) demonstrate the value relevance of foreign income disclosure in the U.S. In this paper we provide evidence for the value-relevance of foreign income disclosures for Australia, Canada and the U.K. Similar to the findings in the U.S. we demonstrate that foreign income changes are more positively associated with annual returns than are domestic income changes. Taken together these results suggest that foreign income is perceived by the market to have 
different economic characteristics than domestic income. Moreover, also consistent with the results from the U.S., we demonstrate that the incremental foreign association coefficient is positively related to a proxy for the incremental degree of growth opportunities in foreign operations. We claim this indicates market participants value foreign income more highly because of the greater degree of growth opportunities they perceive. Finally, these results are largely robust to the addition of income level variables and adjustments for income negative income realizations. 


\section{References}

17 CFR Regulation 210.4-08.paragraph (h) General Notes to Financial Statements - Income Tax Expense.

Ali, A. and P. Zarowin, "The Role of Earnings Levels in Annual Earnings-Returns Studies," Journal of Accounting Research, (Autumn 1992): 286-296.

Alford, A., J. Jones, R. Leftwich and M. Zmijewski, "The Relative Informativeness Accounting Disclosures in Different Countries," Journal of Accounting Research, (Supplement 1993): 183-223.

Ball, R., and P. Brown, "An Empirical Evaluation of Accounting Numbers," Journal of Accounting Research, (Autumn 1968): 159-78.

Barth, M., and G. Clinch, "International Accounting Differences and Their Relation to Share Prices: Evidence from the U.K., Australian, and Canadian Firms," Contemporary Accounting Research, Vol. 13 No. 1 (Spring 1996) pp. 135-170.

Bhagat, S. and I. Welch, "Corporate Research \& Development Investments International Comparisons", Journal of Accounting and Economics (March-May 1995):443-70.

Belsley, D.A., E. Kuh, and R. E. Welsch, Regression Diagnostics. New York:: John Wiley and Sons, 1980.

Boatsman, J. R., B. K. Behn and D. H. Patz, "A Test of the Use of Geographical Segment Disclosures," Journal of Accounting Research, (Supplement 1993): 46-64.

Bodnar, G. M., and J. Weintrop, "The Valuation of Foreign Earnings: A Growth Opportunities Perspective," Journal of Accounting and Economics, Vol 24, 1997.

Chan, K., and G. Seow, "The Association Between Stock Returns and Foreign GAAP Earnings Versus Earnings Adjusted to U.S. GAAP," Journal of Accounting and Economics, Volume 21, No. 1, February 1996, pp 139-158.

Choi, F.D.S. and G.G. Mueller, International Accounting, Second Edition. Englewood Cliffs: Prentice Hall, 1992.

Collins, D. W. and S. P. Kothari, "An Analysis of the Intertemporal and Cross-sectional Determinants of Earnings Response Coefficients," Journal of Accounting and Economics (July 1989):143-81.

Christie, A., "On Cross-Sectional Analysis in Accounting Research", Journal of Accounting And Economics, (1987,9): 231 - 258.

Financial Accounting Standards Board, Statement of Financial Accounting Standards No. 14: Financial Reporting for Segments of a Business Enterprise. Stamford, Conn.: FASB, 1978.

Garrond, N. and W. Rees, "International Diversification and Firm Value," Journal of Business Finance and Accounting, (November/December 1998): 1255-1281.

Hayn, C., "Information Content of Losses", Journal of Accounting And Economics, (1995,20): 123-153. 
Kinney, W., "Covariability of Segment Earnings and Multisegment Company Returns," Accounting Review, (April 1972): 339-45.

Herrmann, D., and W. B. Thomas, "An Analysis of Segment Disclosures under SFAS No. 131 and SFAS No. 14," Accounting Horizons, (September, 2000) vol. 14, no. 3, pp. 287-302.

Ohlson, J., "Earnings, Book Values and Dividends in Equity Valuation", Contemporary Accounting Research (Spring 1995): 661-87.

Rajan, R.G. and L. Zingales, "What Do We Know about Capital Structure? Some Evidence from International Data," Journal of Finance (December 1995):1421-60.

Saudagaran, S., "Discussion of A Test of the Use of Geographical Segment Disclosure," Journal of Accounting Research, (Supplement 1993): 65-74.

Securities and Exchange Commission, Securities Exchange Act of 1933, Release No. 33-4988, Chicago: Commerce Clearing House, July 1969.

Securities and Exchange Commission, Securities Exchange Act of 1933, Release No. 33-4949, Chicago: Commerce Clearing House, February 1969.

Securities and Exchange Commission, Securities Exchange Act of 1934, Release No. 34-9000, Chicago: Commerce Clearing House, October 1970.

Securities and Exchange Commission, General Revision of Regulation SX, Federal Register Vol. 48, No. 188, September 23, 1980.

Swaminathan, S., "The Impact of SEC Mandated Segment Data on Price Variability and Divergence of Beliefs," Accounting Review, (January 1991):23-41.

Thomas, W., "The Value-relevance of Geographic Segment Earnings Disclosures Under SFAS 14", forthcoming, Journal of International Finance and Accounting, 2000.

White, H. "A Heteroscedasticity-Consistent Matrix Estimator and a Direct Test for Heteroscedasticity." Econometrica (May 1098): 817-38. 
Table 1

Sample Characteristics for Australia, Canada, and the United Kingdom from 1990-1998

\section{PANEL A : Australia - Quartiles of Pooled Sample}

$\underline{\text { Variable }}$

Assets (A $\$ M M)$

Market Value (A \$MM)

Foreign Revenues ( $\%$ of total)

Foreign Operating Inc. (\% of total)

Foreign Assets ( $\%$ of total)
$\underline{Q 1}$

278.6

231.8

9.4

0.0

12.1 $\underline{\text { Median }}$

939.2

778.4

23.2

13.9

24.3
Q3

2,973

2,521

37.9

38.8

39.2
$\underline{\mathrm{N}}$

444

444

444

444

444

PANEL B: Canada - Quartiles of Pooled Samples

$\underline{\text { Variable }}$

Assets (C\$MM)

Market Value (C\$MM)

Foreign Revenues (\% of total)

Foreign Operating Inc. ( $\%$ of total)

Foreign Assets ( $\%$ of total)
Q1 $\quad \underline{\text { Median }}$

244.6

152.6

19.0

0.0

16.3
720.5

440.1

45.5

22.7

37.4
Q3

$\underline{\mathrm{N}}$

891

891

891

891

881

\section{PANEL C: United Kingdom - Quartiles of Pooled Samples}

$\underline{\text { Variable }}$

Assets (£MM)

Market Value (£MM)

Foreign Revenues ( $\%$ of total)

Foreign Operating Inc. ( $\%$ of total)

Foreign Assets ( $\%$ of total) $\underline{\text { 1 }}$

83.1

75.6

13.1

4.9

3.2 $\underline{\text { Median }}$

244.6

210.5

37.2

32.9

14.6
Q3

$\underline{\mathrm{N}}$

738

682.4

738

60.3

738

64.8

730

28.6

662

Table Notes: Assets and market values are drawn from Compustat (Global Vantage). Foreign assets, revenues and earnings are from the Disclosure. Q1 is the $25^{\text {th }}$ percentile, Median is the $50^{\text {th }}$ percentile, and Q 3 is the $75^{\text {th }}$ percentile. $\mathrm{N}$ is the number of firm-year observations. 
Table 2

Sample Characteristics for Australia, Canada, and the United Kingdom from 1990-1998

\begin{tabular}{|c|c|c|c|c|c|c|c|c|c|}
\hline$\underline{\text { Variable }}$ & $\underline{\text { Mean }}$ & $\underline{\text { Median }}$ & $\underline{\text { Min }}$ & $\underline{\operatorname{Max}}$ & Q3-Q1 & \multicolumn{3}{|c|}{$\underline{\text { Correlation }}$} & $\underline{\mathrm{N}}$ \\
\hline$\Delta$ TOPEPS $_{\mathrm{t}} / \mathrm{P}_{\mathrm{t}-1}$ & 0.004 & 0.006 & -0.330 & 0.324 & 0.049 & 1.00 & 0.17 & 0.20 & 444 \\
\hline$\Delta$ FOPEPS $_{\mathrm{t}} / \mathrm{P}_{\mathrm{t}-1}$ & 0.003 & 0.000 & -0.277 & 0.316 & 0.007 & & 1.00 & 0.14 & 444 \\
\hline MAR (\%) & 0.006 & -0.040 & -0.689 & 1.236 & 0.436 & & & 1.00 & 444 \\
\hline
\end{tabular}

PANEL B: Canada - Sample Characteristics

\begin{tabular}{|c|c|c|c|c|c|c|c|c|c|}
\hline$\underline{\text { Variable }}$ & Mean & $\underline{\text { Median }}$ & $\underline{\text { Min }}$ & $\underline{\operatorname{Max}}$ & Q3-Q1 & \multicolumn{3}{|c|}{$\underline{\text { Correlation }}$} & $\underline{\mathrm{N}}$ \\
\hline$\Delta$ TOPEPS $_{\mathrm{t}} / \mathrm{P}_{\mathrm{t}-1}$ & 0.007 & 0.011 & -0.783 & 0.654 & 0.072 & 1.00 & 0.37 & 0.30 & 891 \\
\hline$\Delta$ FOPEPS $_{\mathrm{t}} / \mathrm{P}_{\mathrm{t}-1}$ & 0.006 & 0.000 & -0.594 & 0.657 & 0.019 & & 1.00 & 0.21 & 891 \\
\hline MAR (\%) & -0.017 & -0.031 & -0.080 & 2.049 & 0.500 & & & 1.00 & 891 \\
\hline
\end{tabular}

PANEL C: United Kingdom - Sample Characteristics

\begin{tabular}{|c|c|c|c|c|c|c|c|c|c|}
\hline \multirow{2}{*}{$\begin{array}{l}\text { Variable } \\
\Delta \text { TOPEPS }_{\mathrm{t}} / \mathrm{P}_{\mathrm{t}-1}\end{array}$} & Mean & Median & Min & $\underline{\operatorname{Max}}$ & Q3-Q1 & \multicolumn{3}{|c|}{ Correlation } & $\underline{\mathrm{N}}$ \\
\hline & 0.007 & 0.011 & -0.011 & 0.228 & 0.039 & 1.00 & 0.34 & 0.34 & 738 \\
\hline$\Delta$ FOPEPS $_{\mathrm{t}} / \mathrm{P}_{\mathrm{t}-1}$ & 0.002 & 0.000 & -0.146 & 0.113 & 0.012 & & 1.00 & 0.18 & 738 \\
\hline MAR (\%) & -0.035 & -0.047 & -0.759 & 1.096 & 0.370 & & & 1.00 & 738 \\
\hline
\end{tabular}


Table 3

Cross-Sectional Association Regressions of Market Adjusted Returns and Changes in Earnings by Country

\section{Panel A: Total Operating Earnings and Non-Operating Earnings}

$$
\text { MAR }_{\mathrm{i}, \mathrm{t}}=\alpha_{0}+\alpha_{1} \frac{\Delta \text { TOPEPS }_{\mathrm{i}, \mathrm{t}}}{\mathrm{P}_{\mathrm{i}, \mathrm{t}-1}}+\alpha_{2} \frac{\Delta \text { TNOPEPS }_{\mathrm{i}, \mathrm{t}}}{\mathrm{P}_{\mathrm{i}, \mathrm{t}-1}}+\varepsilon_{\mathrm{i}, \mathrm{t}}^{1}
$$

\begin{tabular}{lccccc} 
& $\alpha_{0}$ & $\alpha_{1}$ & $\alpha_{2}$ & Adj. $\mathrm{R}^{2}$ & $\mathrm{~N}$ \\
\hline Australia & 0.00 & 1.15 & 0.72 & 0.10 & 444 \\
& $(0.04)$ & $(6.07)^{\mathrm{a}}$ & $(5.56)^{\mathrm{a}}$ & & \\
Canada & -0.02 & 1.06 & 0.02 & 0.09 & 891 \\
& $(-1.60)^{\mathrm{b}}$ & $(9.07)^{\mathrm{a}}$ & $(1.91)^{\mathrm{b}}$ & & \\
United & -0.05 & 1.94 & 0.24 & 0.12 & 738 \\
Kingdom & $(-4.45)^{\mathrm{a}}$ & $(9.32)^{\mathrm{a}}$ & $(3.01)^{\mathrm{a}}$ & &
\end{tabular}

PANEL B: Total Operating Income, Non-Operating Earnings and Foreign Earnings

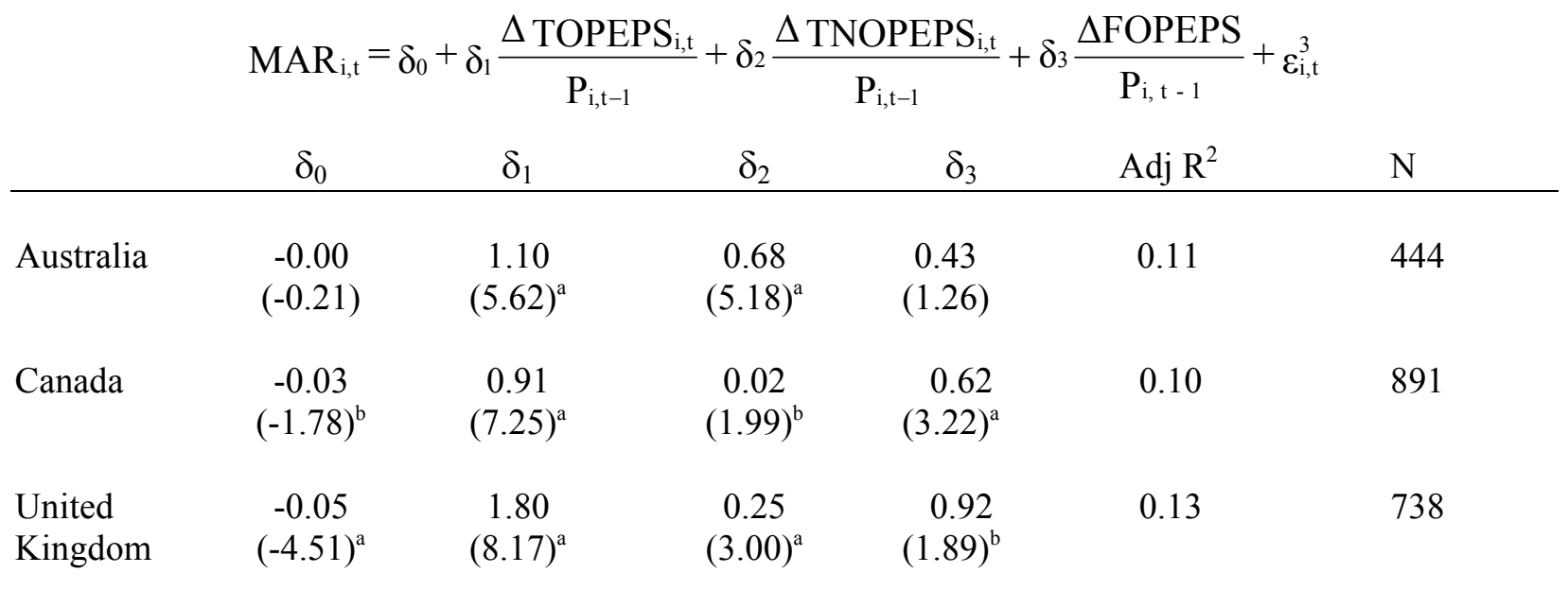

Table Notes: Panel A: $\mathrm{MAR}_{\mathrm{i}, \mathrm{t}}$ is the cumulative market adjusted return for firm i over the 12-month period. $\triangle$ TOPEPS $_{i, t}$ is the change in total operating earnings for firm $i$ from fiscal year $t-1$ to fiscal year $t ; \Delta$ TNOPEPS $_{i, t}$ is the change in non operating income (the difference between a firm's operating income and net income) for firm $\mathrm{i}$ from fiscal year $\mathrm{t}-1$ to fiscal year $\mathrm{t}$ and $\triangle \mathrm{FOPEPS}_{\mathrm{i}, \mathrm{t}}$ is the change in the foreign component of earnings for firm $\mathrm{i}$ from fiscal year $\mathrm{t}-1$ to fiscal year t. $\mathrm{P}_{\mathrm{i}, \mathrm{t}-1}$ is the price of firm i's equity at time $\mathrm{t}-1$, used as a normalization for the income data. All regression are OLS. t-statistics are shown in parentheses based upon the White (1980) corrected standard errors. ${ }^{\mathrm{a}}{ }^{\mathrm{b}}$ and ${ }^{\mathrm{c}}$ represent statistical significance at the 1,5 , and 10 percent levels respectively for onetailed tests. 
Table 4

Relation Between Market Adjusted Annual Return and Total, Foreign, and Other Earnings By Relative Growth Rates of Foreign and Domestic Sales

$$
M A R_{i, t}=\delta_{0}+\delta_{1} \frac{\Delta T O P E P S_{i, t}}{P_{i, t-1}}+\delta_{2} \frac{\Delta T N O P E P S_{i, t}}{P_{i, t-1}}+\delta_{3} \frac{\Delta F O P E P S_{i, t}}{P_{i, t-1}}+\varepsilon_{i, t}
$$

\section{Panel A: Domestic Sales Growth > Foreign Sales Growth}

\begin{tabular}{lcccccc} 
& $\delta_{0}$ & $\delta_{1}$ & $\delta_{2}$ & $\delta_{3}$ & $\operatorname{Adj~R}^{2}$ & $\mathrm{~N}$ \\
\hline \multirow{2}{*}{ Australia } & 0.01 & 1.58 & 1.23 & -1.01 & 0.11 & 224 \\
& $(0.48)$ & $(5.13)^{\mathrm{a}}$ & $(4.44)^{\mathrm{a}}$ & $(-1.64)^{\mathrm{c}}$ & & \\
Canada & -0.01 & 1.04 & 0.01 & 0.18 & 0.08 & 441 \\
& $(-0.61)$ & $(5.52)^{\mathrm{a}}$ & $(1.27)$ & $(0.60)$ & & \\
United & -0.04 & 2.11 & 0.24 & 0.66 & 0.13 & 420 \\
Kingdom & $(-3.00)^{\mathrm{a}}$ & $(6.86)^{\mathrm{a}}$ & $(1.98)^{\mathrm{b}}$ & $(0.93)$ & &
\end{tabular}

Panel B: Foreign Sales Growth $\geq$ Domestic Sales Growth

\begin{tabular}{lcccccc} 
& $\delta_{0}$ & $\delta_{1}$ & $\delta_{2}$ & $\delta_{3}$ & $\operatorname{Adj~R}^{2}$ & $\mathrm{~N}$ \\
\hline \multirow{2}{*}{ Australia } & -0.02 & 0.79 & 0.50 & 1.22 & 0.13 & 220 \\
& $(-0.99)$ & $(3.22)^{\mathrm{a}}$ & $(3.71)^{\mathrm{a}}$ & $(3.19)^{\mathrm{a}}$ & & \\
Canada & -0.05 & 0.81 & 0.07 & 0.96 & 0.12 & 450 \\
& $(-2.27)^{\mathrm{b}}$ & $(4.83)^{\mathrm{a}}$ & $(2.34)^{\mathrm{a}}$ & $(4.03)^{\mathrm{a}}$ & & \\
United & -0.06 & 1.41 & 0.26 & 1.26 & 0.13 & 318 \\
Kingdom & $(-3.58)^{\mathrm{a}}$ & $(4.44)^{\mathrm{a}}$ & $(2.27)^{\mathrm{a}}$ & $(1.91)^{\mathrm{b}}$ & &
\end{tabular}

Table Notes: MARi,t is the cumulative market adjusted return for firm i over the 12-month period. $\triangle$ TOPEPSi,t is the change in total operating earnings for firm i from fiscal year $\mathrm{t}-1$ to fiscal year $\mathrm{t}$; $\triangle$ TNOPEPSi, $\mathrm{t}$ is the change in non operating income (the difference between a firm's operating income and net income) for firm i from fiscal year $\mathrm{t}-1$ to fiscal year $\mathrm{t}$ and $\triangle \mathrm{FOPEPSi}, \mathrm{t}$ is the change in the foreign component of earnings for firm $\mathrm{i}$ from fiscal year $\mathrm{t}-1$ to fiscal year t. Pi,t-1 is the price of firm i's equity at time t-1, used as a normalization for the income data. Observations are broken down across panels based on relative sales growth for the foreign and domestic segment from the prior year. t-statistics based upon White (1980) corrected standard error are reported in parentheses. ${ }^{\mathrm{a}}$, $^{\mathrm{b}}$ and ${ }^{\mathrm{c}}$ represent statistical significance at the 1,5 and 10 percent levels respectively for one-tailed tests. 
Table 5

Relation Between Market Adjusted Annual Return and Total, Foreign and Other Earnings Changes and Levels Controlling for Negative Earnings for Firms

By Relative Growth Rates of Foreign and Domestic Sales

$$
\begin{aligned}
M_{A R} R_{i, t} & =\omega_{0}+\omega_{1} \frac{\text { TOPEPS }_{i, t}}{P_{i, t-1}} \omega_{2} \frac{N E G_{-} \text {TOPEPS }_{i, t}}{P_{i, t-1}}+\omega_{3} \frac{\Delta T O P E P S_{i, t}}{P_{i, t-1}}+\omega_{4} \frac{N E G_{-} \Delta \text { TOPEPS }_{i, t}}{P_{i, t-1}}+\omega_{5} \frac{\text { FOPEPS }_{i, t}}{P_{i, t-1}} \\
& +\omega_{6} \frac{N E G_{-} F O P E P S_{i, t}}{P_{i, t-1}}+\omega_{7} \frac{\Delta F O P E P S_{i, t}}{P_{i, t-1}}+\omega_{8} \frac{N E G_{-} \Delta F O P E P S_{i, t}}{P_{i, t-1}}+\omega_{9} \frac{T N O P E P S_{i, t}}{P_{i, t-1}}+\omega_{10} \frac{\Delta T N O P E P S_{i, t}}{P_{i, t-1}}+\varepsilon_{i, t}
\end{aligned}
$$

\begin{tabular}{|c|c|c|c|}
\hline & Australia & Canada & United Kingdom \\
\hline$\omega_{0}$ & $\begin{array}{c}-0.08 \\
(-1.96)^{b}\end{array}$ & $\begin{array}{c}-0.02 \\
(-0.83)\end{array}$ & $\begin{array}{c}-0.15 \\
(-6.93)^{\mathrm{a}}\end{array}$ \\
\hline$\omega_{1}$ & $\begin{array}{c}1.78 \\
(4.32)^{\mathrm{a}}\end{array}$ & $\begin{array}{c}0.44 \\
(3.23)^{\mathrm{a}}\end{array}$ & $\begin{array}{c}1.11 \\
(5.33)^{\mathrm{a}}\end{array}$ \\
\hline$\omega_{2}$ & $\begin{array}{l}-0.01 \\
(-1.27)\end{array}$ & $\begin{array}{c}-0.30 \\
(-0.82)\end{array}$ & $\begin{array}{l}-1.74 \\
(-1.19)\end{array}$ \\
\hline$\omega_{3}$ & $\begin{array}{c}0.34 \\
(0.66)\end{array}$ & $\begin{array}{c}0.84 \\
(2.97)^{\mathrm{a}}\end{array}$ & $\begin{array}{c}2.43 \\
(7.06)^{\mathrm{a}}\end{array}$ \\
\hline$\omega_{4}$ & $\begin{array}{c}0.40 \\
(0.68)\end{array}$ & $\begin{array}{c}0.21 \\
(0.56)\end{array}$ & $\begin{array}{c}-2.53 \\
(-3.96)^{\mathrm{a}}\end{array}$ \\
\hline$\omega_{5}$ & $\begin{array}{c}-0.96 \\
(-2.24)\end{array}$ & $\begin{array}{c}0.23 \\
(1.19)\end{array}$ & $\begin{array}{c}-0.16 \\
(-0.61)\end{array}$ \\
\hline$\omega_{6}$ & $\begin{array}{c}1.82 \\
(0.69)\end{array}$ & $\begin{array}{c}0.48 \\
(0.80)\end{array}$ & $\begin{array}{l}-11.05 \\
(-2.55)^{\mathrm{a}}\end{array}$ \\
\hline$\omega_{6}$ & $\begin{array}{c}0.74 \\
(0.86)\end{array}$ & $\begin{array}{c}-0.07 \\
(-0.16)\end{array}$ & $\begin{array}{c}0.51 \\
(1.78)^{\mathrm{b}}\end{array}$ \\
\hline$\omega_{7}$ & $\begin{array}{c}-2.68 \\
(-1.68)\end{array}$ & $\begin{array}{c}-0.24 \\
(-0.39)\end{array}$ & $\begin{array}{c}0.66 \\
(2.35)^{\mathrm{b}}\end{array}$ \\
\hline$\omega_{8}$ & $\begin{array}{c}1.31 \\
(3.02)^{\mathrm{a}}\end{array}$ & $\begin{array}{c}0.47 \\
(4.03)^{\mathrm{a}}\end{array}$ & $\begin{array}{c}0.56 \\
(2.45)^{\mathrm{b}}\end{array}$ \\
\hline$\omega_{9}$ & $\begin{array}{c}0.25 \\
(0.64)\end{array}$ & $\begin{array}{c}0.00 \\
(0.90)\end{array}$ & $\begin{array}{c}0.10 \\
(1.40)\end{array}$ \\
\hline ations & 224 & 441 & 420 \\
\hline & 0.20 & 0.12 & 0.25 \\
\hline
\end{tabular}

\section{Panel A: Domestic Sales Growth > Foreign Sales Growth}




$$
\begin{aligned}
& \text { MAR }_{i, t}=\omega_{0}+\omega_{1} \frac{\text { TOPEPS }_{i, t}}{P_{i, t-1}} \omega_{2} \frac{N E G_{-} \text {TOPEPS }_{i, t}}{P_{i, t-1}}+\omega_{3} \frac{\Delta \text { TOPEPS }_{i, t}}{P_{i, t-1}}+\omega_{4} \frac{N E G_{-} \Delta \text { TOPEPS }_{i, t}}{P_{i, t-1}}+\omega_{5} \frac{\text { FOPEPS }_{i, t}}{P_{i, t-1}} \\
& \quad+\omega_{6} \frac{N E G_{-} \text {FOPEPS }_{i, t}}{P_{i, t-1}}+\omega_{7} \frac{\Delta F O P E P S_{i, t}}{P_{i, t-1}}+\omega_{8} \frac{N E G_{-} \Delta F O P E P S_{i, t}}{P_{i, t-1}}+\omega_{9} \frac{\text { TNOPEPS }_{i, t}}{P_{i, t-1}}+\omega_{10} \frac{\Delta T N O P E P S_{i, t}}{P_{i, t-1}}+\varepsilon_{i, t}
\end{aligned}
$$

\begin{tabular}{|c|c|c|c|}
\hline & Australia & Canada & United Kingdom \\
\hline$\omega_{0}$ & $\begin{array}{c}-0.15 \\
(-4.12)^{\mathrm{a}}\end{array}$ & $\begin{array}{c}-0.07 \\
(-2.51) b\end{array}$ & $\begin{array}{c}-0.12 \\
(-3.74)^{\mathrm{a}}\end{array}$ \\
\hline$\omega_{1}$ & $\begin{array}{c}1.80 \\
(4.50)^{\mathrm{a}}\end{array}$ & $\begin{array}{c}0.07 \\
(0.49)\end{array}$ & $\begin{array}{c}0.63 \\
(2.06)^{\mathrm{a}}\end{array}$ \\
\hline$\omega_{2}$ & $\begin{array}{c}-1.20 \\
(-2.29)^{\mathrm{b}}\end{array}$ & $\begin{array}{c}0.53 \\
(0.88)\end{array}$ & $\begin{array}{c}0.91 \\
(0.54)\end{array}$ \\
\hline$\omega_{3}$ & $\begin{array}{c}0.43 \\
(0.74)\end{array}$ & $\begin{array}{c}0.98 \\
(4.10) \mathrm{a}\end{array}$ & $\begin{array}{c}1.38 \\
(3.11)^{\mathrm{a}}\end{array}$ \\
\hline$\omega_{4}$ & $\begin{array}{l}-0.09 \\
(0.14)\end{array}$ & $\begin{array}{l}-0.46 \\
(-1.21)\end{array}$ & $\begin{array}{l}-1.04 \\
(-1.44)^{\mathrm{c}}\end{array}$ \\
\hline$\omega_{5}$ & $\begin{array}{c}0.04 \\
(0.53)\end{array}$ & $\begin{array}{c}0.03 \\
(0.13)\end{array}$ & $\begin{array}{l}-0.07 \\
(-0.20)\end{array}$ \\
\hline$\omega_{6}$ & $\begin{array}{c}-3.36 \\
(-1.98)^{b}\end{array}$ & $\begin{array}{c}0.93 \\
(1.40) \mathrm{c}\end{array}$ & $\begin{array}{l}-2.62 \\
(-0.63)\end{array}$ \\
\hline$\omega_{6}$ & $\begin{array}{c}0.57 \\
(1.27)\end{array}$ & $\begin{array}{c}1.44 \\
(3.42)^{\mathrm{a}}\end{array}$ & $\begin{array}{c}1.47 \\
(1.99)^{\mathrm{b}}\end{array}$ \\
\hline$\omega_{7}$ & $\begin{array}{c}2.87 \\
(1.92)^{b}\end{array}$ & $\begin{array}{c}-1.47 \\
(-2.85)^{\mathrm{a}}\end{array}$ & $\begin{array}{c}-1.22 \\
(-0.40)\end{array}$ \\
\hline$\omega_{8}$ & $\begin{array}{c}0.97 \\
(3.22)^{\mathrm{a}}\end{array}$ & $\begin{array}{c}-0.12 \\
(-1.38)^{\mathrm{c}}\end{array}$ & $\begin{array}{c}0.11 \\
(0.58)\end{array}$ \\
\hline$\omega_{9}$ & $\begin{array}{c}0.22 \\
(1.45)^{\mathrm{c}}\end{array}$ & $\begin{array}{c}0.27 \\
(1.71)^{\mathrm{c}}\end{array}$ & $\begin{array}{c}0.22 \\
(1.38)^{\mathrm{c}}\end{array}$ \\
\hline tions & 220 & 450 & 318 \\
\hline & 0.20 & 0.11 & 0.12 \\
\hline
\end{tabular}

Panel B: Foreign Sales Growth $\geq$ Domestic Sales Growth

Table Notes: TOPEPS ${ }_{i, t}$ is the level of total operating earnings for firm $i$ for fiscal year $t ;$ FOPEPS $_{i, t}$ is the level of foreign operating earnings for firm $i$ in fiscal year $t$; TNOPEPS $_{i, t}$ is the level of net non-operating earnings for firm $i$ from fiscal year t. $\triangle$ TOPEPS $_{i, t}$ is the change in total earnings for firm $\mathrm{i}$ from fiscal year $\mathrm{t}-1$ to fiscal year $\mathrm{t}$. $\triangle$ FOPEPS $_{\mathrm{i}, \mathrm{t}}$ is the change in the foreign earnings component for firm $\mathrm{i}$ from fiscal year $\mathrm{t}-1$ to fiscal year. $\triangle$ TNOPEPS $_{i, t}$ is the change in the difference between a firm's net operating income and total net income for firm $i$ from fiscal year t-1 to fiscal year t. When the variable if professed by NEG, this represents a dummy variable set to 1 if the attached value is negative. $P_{i, t-1}$ is the price of firm i's equity at beginning of the return accumulation period and is used to normalize the income data. t-statistics based upon White (1980) corrected standard error are reported in parentheses. ${ }^{\mathrm{a}}{ }^{\mathrm{b}}{ }^{\text {and }}{ }^{\mathrm{c}}$ represent statistical significance at the 1,5 and 10 percent levels respectively for one-tailed tests. 